\title{
Serial Copulatory Behavior of Male Hamsters and Rats
}

\author{
Takao YAMAGUCHI, Masao KOIDE and Toru R. SAITO* \\ Toxicology Division, Institute of Environmental Toxicology, 2-772 Suzuki-cho, \\ Kodaira-shi, Tokyo 187, Japan and *Department of Pharmacology, Kyorin \\ University School of Medicine, 6-20-2 Shinkawa, Mitaka-shi, \\ Tokyo 181
}

(Received 15 April 1988/Accepted 6 July 1988)

\begin{abstract}
The copulatory behavior of mammalian males is generally characterized by the male's repeated approaches to and mounting of the female. The mounting behavior can lead to intromission, and after several intromissions, an ejaculation occurs. Following ejaculation, the male refrains from sexual activity for a period of time, the so-called "post-ejaculatory interval (PEI)". Most mammals will return to copulate again. Both male hamsters and rats were used and each animal performed five series of copulations with a proestrous female. From the 1 st to 5 th series of copulations the hamsters showed a shorter PEI than the rats. In addition, the PEI of the hamsters showed no change after each ejaculation, while the rats gradually showed a significantly increased PEI during the five series of copulations.
\end{abstract}

\section{雄ハムスターおよびラットに拈ける交尾行動の \\ 時間的推移について}

山口孝雄·小出正雄・斎藤 徹*

(財)残留農薬研究所毒性部動物管理室

*杏林大学医学部楽理学教室

成熟雄動物は, 発情している雌動物およびホルモンで 発情を誘起された動物と一緒にすると, マウント，局部 の挿入, 射精そして性的不応期といった一連の交尾行動 を示す。雌の導入から性的不応期の終了までを 1 回の射 精シリーズと呼ばれている。一般的に，射精シリーズが 数回繰り返されたのちに雄は性的飽和に至ると考えられ ている。

今回, 我々は雄ハムスターおよびラットにおける交尾
行動の時間的推移について観察したので報告する。

供試動物：動物は日本生物科学研究所より生後 4 週齿 で購入したGN系ゴールデンハムスターの雌雄ならびに 日本チャールズ・リバーより 4 週齢で購入した Wistar 系ラットの雌雄を用いた。

飼育環境: 温度 $24 \pm 2{ }^{\circ} \mathrm{C}$, 湿度 $55 \pm 10 \%$, 換気回数 1 時間12回 (オールフレッシュエアー方式), 人工照明時 間 1 日14時間（午前 5 時点灯, 午後 7 時消灯）に設定さ 
れた飼育室で, ハムスターはアルミ製弁当箱型ケージ $(26 \mathrm{~W} \times 40 \mathrm{D} \times 20 \mathrm{H} \mathrm{cm})$ に木製チップを床敷として用い， ラットはステンレス製金網ケージ $(31 \mathrm{~W} \times 44 \mathrm{D} \times 23 \mathrm{Hcm})$ にて，それぞれ 4 〜 匹ずつ飼育された。

飼料・水：飼料は固型飼料（ハムスター：オリエンタ ル酵母社製 NMF，ラット：同社製 MF）とし，飽食さ せ，水を絶やさないようにした。

観察条件：ハムスター扰よびラットの雌雄ともにそれ ぞれ生後 8〜10週粭より交尾行動の観察実験を行った。 此は観察実験に先立ち $6 \sim 8$ 週齿より腔垢の採取が行わ れた $[6,8] 。 4$ 日性周期を連続して 3 回以上綝り返し た個体のみを垁験に供した。交尾行動の観察には, 交尾 未経験雄ハムスターおよびラットをそれぞれ７匹ずつ用 いた。観察は午後 7 時より赤色ライト $(6 \mathrm{~W})$ 下で行わ れ，射精シリーズが 5 回に達した時点で観察を終了した。 即ち, 最初に雄 1 匹を観察ケージ（ハムスター：半径 24 ×縦 $36 \mathrm{~cm}$, ラット：半径 $40 \times$ 縦 $50 \mathrm{~cm} ）$ に置き, その 5 分 後, 発情前期像を示した雌 1 匹をそれぞれ導人した。記 録にはパーソナルコンピュータ (NEC) を用い, 交尾行 動を次の各指標を用いて定量的に表わした（Fig. 1 参 癹) $[5]$ 。

1. Mount latency (ML)：雄を雌と一緒にしてから 最初のマウント（M）が起こるまでの潜伏時間。

2. Intromission latency (IL) : 雌と一緒にしてから 最初のペニス捜入（I）が起こるまでの潜時。

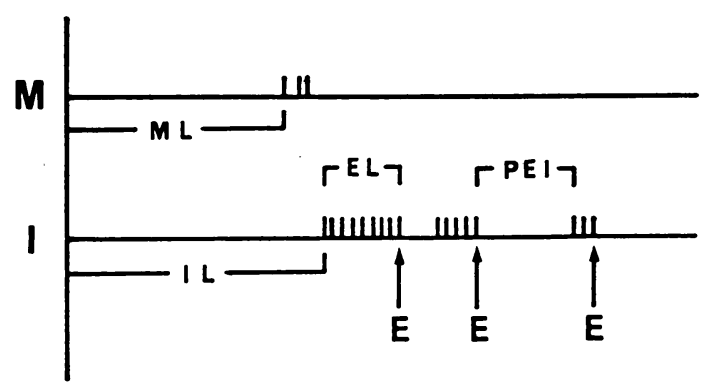

Fig. 1. Pattern and standard measures of copulatory behavior in male animals. Time moves from left to right

(M) Mounting; (I) Intromission; (E) Ejaculation: (ML) Mounting latency; (IL) Intromission latency; (EL) Ejaculation latency ; (PEI) Postejaculatory interval

3. Ejaculation latency (EL) : 各シリーズの最初の I から射精（E）が起こるまでの潜時。

4. Post-ejaculatory interval (PEI) : 性的不心期の 時間で $\mathrm{E}$ から次のシリーズの最初のI が起こるまで の潜時。

5. Mount frequency (MF) : Mの回数。

6. Intromission frequency (IF)：I の回数。

7. Hit rate $(\mathrm{HR}): \mathrm{IF} /(\mathrm{MF}+\mathrm{IF})$ 。

8. Inter intromission interval (III) $: \mathrm{EL} / \mathrm{IF}$ 。

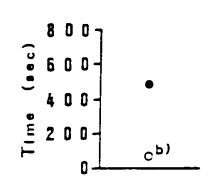

Mounting
Latency

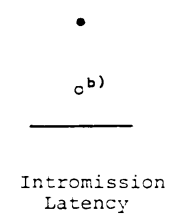

Latency

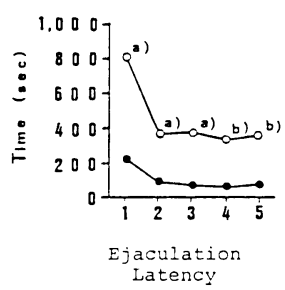

Latency

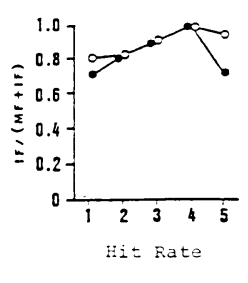

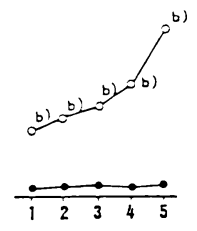

Post-ejaculatory Interval
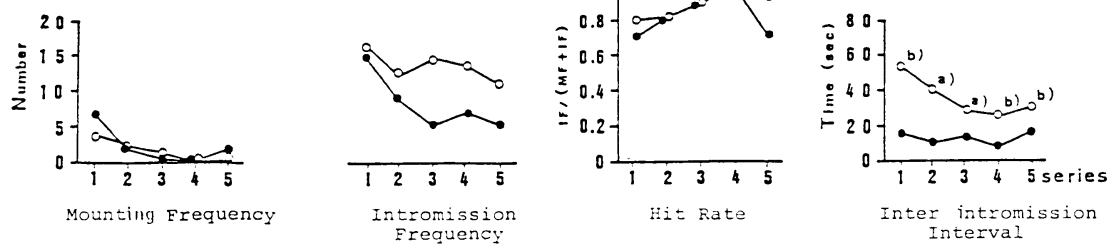

Fig. 2. Copulatory behavior in male hamsters (solid circles) and rats (open circles). Each circle represents the mean of 7 males. Significance levels were calculated by the Mann-Whitney U test $(a, p<0.05 ; b, p<0.01)$. 
M, I および $\mathrm{E} の$ 各行動の詳細については, 山口・斎 藤の報告に記述されている $[9]$ 。本報に扔いても，それ

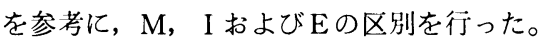

統計処理：最初の射精シリーズ（シリーズ1）に対 する第 2 回目以降の射精シリーズの各值については Wilcoxon signed ranck test [10] で, 雄ハムスターと ラットの各指標の成績については Mann-Whitney U test [4] で統計処理をそれぞれ行った。

雄:ハムスターの交尾行動の時間的推移 (Fig. 2)

雌雄间居後半均 483 秒で最初のMが，601 秒で最初の I が起こり，7.0回のM，16.0回つ I で射精に至った。 その後, PEI が 84 秒間持䋉し, 第 2 シリーズの最初の I が観察された。

シリーズ 2 以降の EL は 63〜121 秒であり, シリーズ 1 の值（299 秒）よりも著しく短い潜時を示し，特にシ リーズ $4 ， 5$ で統計的に有意な差異がみられた（ $\mathrm{p}<$ 0.01)。MF はシリーズ 4 が 0.3 回であり, シリーズ 1 （9.8 回）に対して有意に低い值を示した $(\mathrm{p}<0.01)$ 。 また，IFもシリーズ 1 (16.0国) に刘してシリーズ 3 が 6.0 回と有意任低い值を示した $(\mathrm{p}<0.01)$ 。なお， PEI ならびに HR は各シリーズとも有意差を示さなか ったが, III はシリーズ 1（18.8）に刘してシリーズ4 （8.6）が有意に低值を示した $(\mathrm{p}<0.01)$ 。

婎ラットの交尾行動の時間的推移 (Fig. 2)

雌雄们居後平均70秒で最初のMが， 211 秒で最初の I が起こり，4.0 回のM，16.7回の I で射精に至った。そ の後, PEI が 387 秒間持続し, 第 2 シリーズの最初のI が観察された。

シリーズ 2 以降の ELは320〜381秒であり，シリーズ 1 の值（835 秒）よりあ著しく短い潜時であった（ $\mathrm{p}<$ 0.01)。MF はシリーズ $4 ， 5$ ともそれぞれ0.1，0.6 回 であり，シリーズ 1 (4.0回) 亿対して有意に低い值を 示したが $(\mathrm{p}<0.01)$, IF は各シリーズともほぼ同じ值 を示した。これらの結果, シリーズ1に対してHRはシ リーズ 4,5 で高い值を, III はシリーズ 3 以降低い值 をそれぞれ示した $(\mathrm{p}<0.01)$ 。一方，PEI はシリーズ 1 (387 秒) 亿対してシリーズ 2 以降 (469 990秒) 有 意に延長した $(\mathrm{p}<0.01)$ 。

以上の成績より，ML および IL は八ムスターがラッ トに比較して約 7 倍および 3 倍の時間をそれぞれ要した

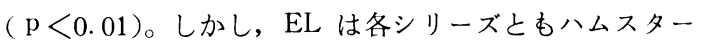
がラットに比較して短い潜時を示した $(\mathrm{p}<0.05 \sim 0.01)$ 。 また, PEI あ各シリーズとあ八ムスターがラットよりあ 短時間であった $(\mathrm{p}<0.01)$ 。
さらに, PEI と射精シリーズ回数との関係についてみ ると，ラットはシリーズ回数に伴い漸次延長する傾向が 認められたが，ハムスターではシリーズ 1 から 5 までほ ぼ同じ值で推移した。一般的に，雄動物は 1 匹の同一雌 之連続的に交尾行動が行われると, PEI がシリ一ズ回数 に伴い漸次延長するといわれている $[1-3,5]$ 。乙の点 に関して，八ムスタ一は特異的な存在であると思われる。

雌雄问居後, シリーズ 5 までに要した時間についてみ ると，ハムスターが平诗26分であったのに対し，ラット では約50分と八ムスターの約 2 倍の時間を必要とした。 高橋ら [7]によると, IVCS 系マウスが最初の射精に至 るまでの潜時は雌雄闰居後, 米圴 5 時間35分であると報 告している。

以上の如く，八ムスター, ラット扰よびマウス [7]の 交尾行動の時間的推移には種の特異性があるととが示㖫 された。今後, 他の動物種についても, 条件を同様にし て詳練な交尾行動の観察を行うことにより,さらに交尾 行動における動物種差が明らかになるものと思われる。

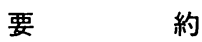

雄動物は雌動物に対して, マゥント, 局部の挿入, 射 精, そして性的不応期といった一連の射精シリーズを示 す。今问, 雉ハムスターの射精シリーズを通常, 性行動 の実験に数多く用いられているラットと比較観察した。 両者に扔ける顕著な差買は, 各射精シリーズの性的不匛 期の時間㧍よび射精シリーズの回数に伴う性的不応期の 時間的推移であった。即ち，八ムスターはラットに比較 し，各射精シリーズとも性的不心期の時間が短く，また 射精シリーズ間でほぼ同じ值で推移した。ラットの性的 不応期の時間は射精シリーズ回数に伴い延長した。

本研究に対してご助言, ご鞭撻を睗わった残留農薬研究所理

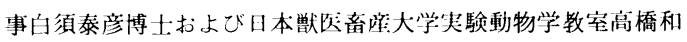
明教授に樑謝する。また，本論文のご校閲を踢わった杏林大学 医学部薬理学教室稲葉稔教授, 中村翰婎助教授および鎌田捗沓 講師に感謝する。

\section{文献}

[1] Beamer, W., Bermant, G., and Clegg, M. T. (1969). Anim. Behav., 17, 706-711.

[2] Fowler, H. and Whalen, R. (1961). J. Comp. Physiol. Psychol., 54, 68-71.

[3] Hsiao, S. (1965). J. Comp. Physiol. Psychol., 60, 467-469. 
[4] Mann, H. B. and Whitney, D. R. (1947). Ann. Math. Statist., 18, 50-60.

［5］村越 等・斎藤 徹 (1987). 実験動物, 36, 443-448.

[6] 信永利馬・中村勝美 (1968). 家畜繁殖誌, 14, 1-7.

[ 7 ] 高橋和明 - 斎藤 徹 - 鈴木通弘 - 天尾弘実 - 外尾亮治 - 若
藤靖匡（1984），実験動物技術，19，28-40。

［8］山口孝雄 - 小出正雄・高橋和明 (1987). 実験動物技術. $22,39-47$

［9］山口孝雄・斎藤 徹 (1987). 実験動物，36, 209-212.

[10] Wilcoxon, F. (1945). Biometrics, 1, 80-83. 